\title{
СИНТЕЗ ПРОЛЕКАРСТВ ГРИЗЕОФУЛЬВИНА НА ОСНОВЕ ОКСИМОВ И ГИДРАЗОНОВ
}

\author{
М.М. Хисамов ${ }^{1,2}$, П.Н. Сольев \\ ${ }^{1}$ Институт молекулярной биологии имени В.А. Энгельгардта РАН, Москва, Россия. \\ ${ }^{2}$ Химический факультет Московского государственного университета \\ им. М.В. Ломоносова, Москва, Россия.
}

DOI: 10.19163/MedChemRussia2021-2021-332

E-mail: hisamovmaratag@mail.ru

Гризеофульфин является соединением с широким спектром фармакологического применения благодаря фунгистатическим свойствам. Однако использование гризеофульвина в фармакологии ограничено низкой растворимостью в воде и, как следствие, низкой пероральной биодоступностью. Расширить применение гризеофульвина можно за счёт повышения его растворимости с помощью создания оксимов и гидразонов на основе аминооксиметилфосфоновой и гидразинометилфосфоновой кислот, являющихся удобными клик-реагентами. Синтез аминооксиметилфосфоната проводился стандартным путём, в то время как эфиры гидразинометилфосфоната получены впервые по новой реакции в ходе данного проекта.

Противогрибковая и антибактериальная активность полученных гидразонов и оксимов изучается на базе НИИ по изысканию новых антибиотиков имени Г.Ф. Гаузе.

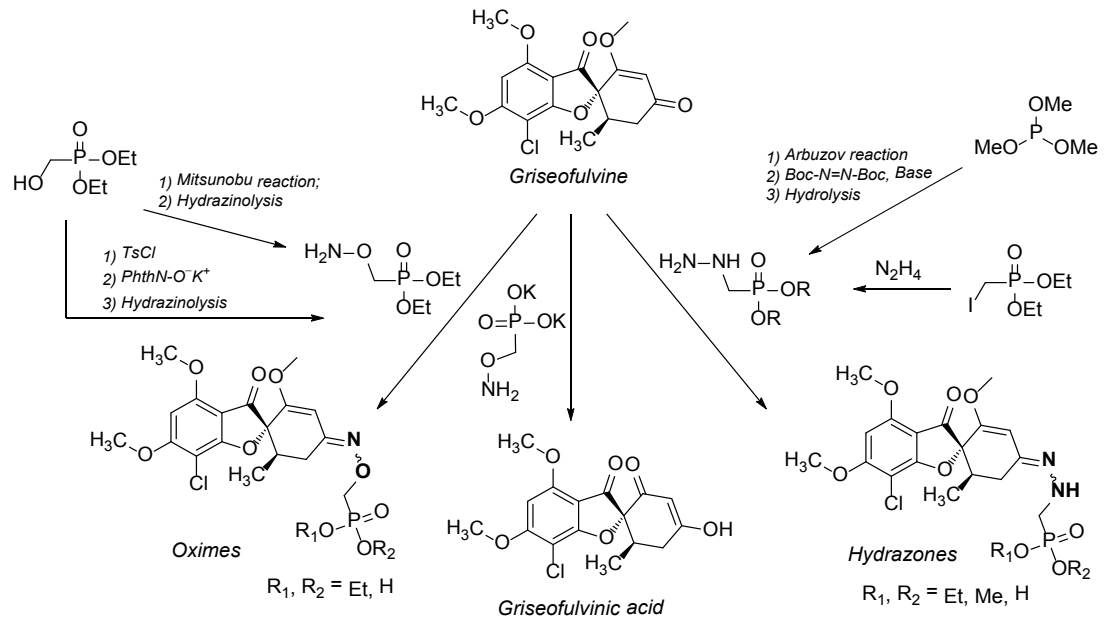

Работа выполнена при финансовой поддержке Российского Научного Фонда (проект № 20-74-10121). Авторы выражают благодарность к.Х.н.Р.А. Новикову за регистрацию спектров ЯМР и к.Х.Н.А.П. Тюрину за проведение экспериментов по изучению антибактериальной и противофунгицидной активности. 